\title{
Pengendalian Level Ketinggian Air pada Bendungan dengan memanfaatkan Komunikasi Data Serial
}

\author{
Lila Yuwana* dan Kurriawan Budi Pranata \\ Jurusan Fisika-FMIPA, Institut Teknologi Sepuluh Nopember \\ Kampus ITS Sukolilo, Surabaya 61111
}

\begin{abstract}
Intisari
Telah dilakukan penelitian tentang perancangan pengendalian level ketinggian air pada bendungan dengan memanfaatkan komunikasi data serial. Sistem ini menggunakan sensor Ping Ultrasonik sebagai monitoring level ketinggian air. Data dari sensor ultrasonik dikirim secara serial dan ditampilkan melalui laptop. Kondisi level ketinggian air ini dapat dikendalikan menggunakan software Delphi melalui media pengkabelan. Berdasarkan hasil penelitian, diperoleh panjang kabel yang digunakan dengan jarak 100 meter, sehingga dapat memberikan wacana tentang pemanfaatan komunikasi data secara serial tidak terbatas hanya pada jarak dekat.
\end{abstract}

KATA KUNCI: sensor ping ultrasonik, data serial, debit air, mini plan bendungan

\section{PENDAHULUAN}

Bendungan merupakan media yang digunakan untuk menampung air. Beberapa kegunaan dari bendungan diantaranya adalah untuk pengairan, pembangkit listrik, dan sarana penanggulangan banjir. Kebanyakan bendungan juga memiliki bagian yang disebut pintu air untuk membuang air yang tidak diinginkan secara bertahap atau berkelanjutan. Ketinggian air pada bendungan dapat dimanfaatkan untuk menghasilkan energi potensial yang nantinya akan digunakan untuk pembangkit listrik. Dengan memanfaatkan teknologi yang ada saat ini pemantauan ketinggian air pada ruang kontrol dapat dilakukan di ruang kontrol yang berjauhan dengan bendungan. Hal ini dilakukan untuk alasan keamanan. Apabila terjadi suatu hal yang tidak diinginkan pada bendungan ruang kontrol masih dalam keadaan aman.

Pada artikel ini dilaporkan pembuatan mini plant pada bendungan dengan menggunakan sensor ping ultrasonik sebagai pendeteksi level ketinggian air dengan menggunakan komunikasi data serial.

\section{TINJAUAN PUSTAKA}

Sebuah bendungan berfungsi untuk meninggikan muka air sungai dan mengalirkan sebagian aliran air sungai ke arah tepi kanan dan tepi kiri sungai untuk mengalirkannya ke dalam saluran melalui sebuah bangunan pengambilan jaringan irigasi. Bendungan juga dapat didefinisikan sebagai bangunan air yang dibangun secara melintang, sedemikian rupa agar permukaan air sungai di sekitarnya naik sampai ketinggian tertentu, sehingga air sungai dapat dialirkan melalui pintu sadap ke saluran-saluran pembagi hingga ke lahan-lahan pertanian [1].

*E-MAIL: 1ila@physics.its.ac.id

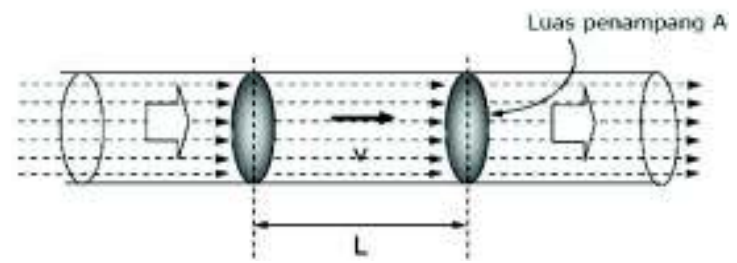

Gambar 1: Debit fluida dalam luasan A.

Pada Gambar 1, fluida mengalir melalui penampang pipa seluas A dan setelah selang waktu t menempuh jarak L. Bila kelajuan aliran fluida v, maka debit fluida $\mathrm{Q}$ dalam pipa adalah

$$
Q=A v\left(m^{3} / s\right)
$$

\section{Sensor Ultrasonik}

Gelombang ultrasonik adalah gelombang dengan besar frekuensi diatas frekuensi gelombang suara $(>20 \mathrm{kHz})$. Sensor ultrasonik terdiri dari rangkaian pemancar ultrasonik (transmitter) dan rangkaian penerima ultrasonik (receiver). Sinyal ultrasonik yang dibangkitkan akan dipancarkan dari transmitter ultrasonik. Ketika sinyal mengenai benda penghalang, maka sinyal ini dipantulkan, dan diterima oleh receiver ultrasonik. Sinyal yang diterima oleh rangkaian receiver dikirimkan ke rangkaian mikrokontroler untuk selanjutnya diolah untuk menghitung jarak terhadap benda di depannya (bidang pantul). Prinsip kerja dari sensor ultrasonik dapat ditunjukkan dalam Gambar 2.

Prinsip kerja dari sensor ultrasonik adalah sebagai berikut :

1. Sinyal dipancarkan oleh pemancar ultrasonik (berfrekuensi diatas $20 \mathrm{kHz}$ ), biasanya yang digunakan untuk mengukur jarak benda adalah $40 \mathrm{kHz}$. Sinyal tersebut di bangkitkan oleh rangkaian pemancar ultrasonik. 


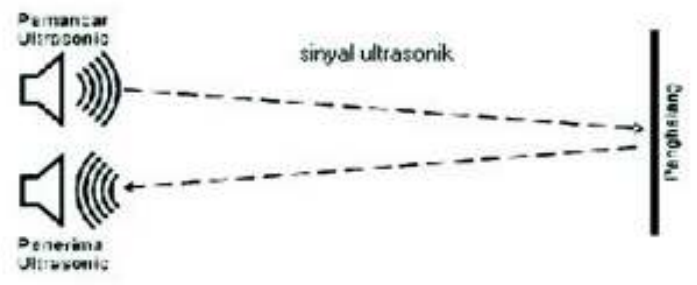

Gambar 2: Sensor ultrasonik.

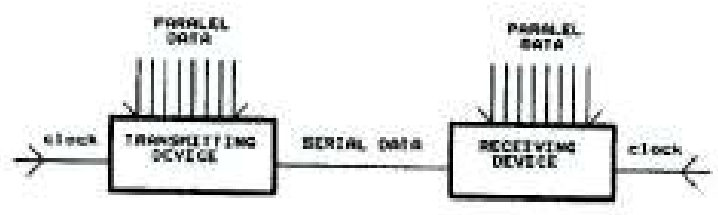

Gambar 3: Blok diagram komunikasi data serial.

2. Sinyal yang dipancarkan tersebut kemudian akan merambat sebagai sinyal atau gelombang bunyi dengan kecepatan bunyi yang berkisar $340 \mathrm{~m} / \mathrm{s}$. Sinyal tersebut kemudian akan dipantulkan dan akan diterima kembali oleh bagian penerima ultrasonik.

3. Setelah sinyal tersebut sampai di penerima ultrasonik, kemudian sinyal tersebut akan diproses untuk menghitung jaraknya. Jarak dihitung berdasarkan rumus :

$$
S=\frac{340 . t}{2}(m)
$$

dengan $\mathrm{S}$ adalah jarak antara sensor ultrasonik dengan bidang pantul, dan $\mathrm{t}$ adalah selisih waktu antara pemancaran gelombang ultrasonik sampai diterima kembali oleh bagian penerima ultrasonik.

\section{Transmisi Data Serial}

Komunikasi secara paralel akan membutuhkan banyak kabel sehingga hal ini menimbulkan ketidak praktisan dan pemborosan. Oleh sebab itu pada transmisi jarak yang jauh, data yang akan dikirim diubah dari bentuk paralel menjadi serial sehingga data tersebut dapat dikirimkan dengan hanya melalui sepasang kabel. Data serial yang diterima kemudian diubah kembali ke dalam bentuk paralel sehingga data tersebut dapat dengan mudah dilewatkan pada bus komputer.

\section{Transmisi Data Asynchronous}

Pada transmisi data asynchronous setiap data karakter mempunyai satu bit yang berfungsi sebagai start bit dan satu atau dua bit yang berfungsi sebagai stop bit. Selain itu setiap data karakter juga dilengkapi dengan bit parity yang

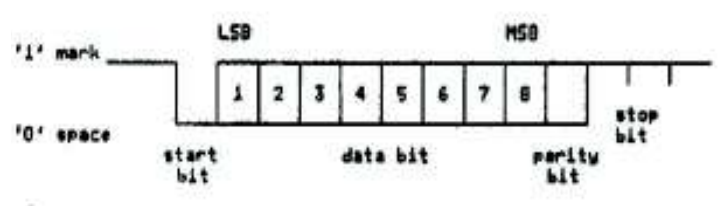

Gambar 4: Format data asynchronous.

berfungsi untuk mendeteksi kesalahan data yang terjadi pada saat transmisi. Karena setiap karakter masing-masing diidentitaskan sendiri, karakter dapat dikirimkan setiap saat (asynchronously) tidak tergantung dengan karakter yang lainnya. Gambar 4 menunjukkan bentuk umum format data transmisi serial asynchronous.

Bilamana tidak ada data yang dikirim, sinyal data akan tetap berlogika 'l', keadaan ini dinamakan marking. Awal dari suatu data karakter ditunjukkan dengan adanya transisi dari keadaan marking menuju logika '0' selama waktu '1' bit. Bit inilah yang dinamakan start bit. Setelah start bit, bit-bit data dikirimkan satu persatu secara bergantian dimulai dengan least significant bit (LSB) dahulu. Data dapat berisi 5, 6,7 , atau 8 bit bergantung pada sistem yang ada. Bit parity dikirimkan setelah bit-bit data selesai ditransmisikan untuk mendeteksi bilamana ada kesalahan saat transmisi berlangsung. Sinyal data kemudian akan berlogika 'l' selama paling sedikit waktu 1 bit untuk menunjukkan bahwa karakter sudah berakhir. Bit yang selalu berlogika 'l' ini dinamakan stop bit.

Transmisi data serial asynchronus ini, kecepatan transmisi dinyatakan dengan istilah baud rate. Dimana baud rate ini didefinisikan sebagai seperwaktu yang diperlukan untuk 1 sel bit. Bilamana waktu yang diperlukan 1 sel bit sebesar 3,33 ms maka baud rate adalah 1/3,33 atau sebesar 300 bps. Baud rate yang umum digunakan pada komunikasi serial adalah 110, 300, 1200, 2400, 4800, 9600, 19200 bps. Untuk membuat suatu interface antara suatu komputer mikro dengan jalur data serial, maka pada sisi kirim data harus diubah dari paralel menjadi serial dan pada sisi terima data harus diubah dari serial menjadi paralel. Untuk itu diperlukan suatu 'paralel-in serial-out shift register' pada sisi kirim dan 'serial-in paralelout shift register' pada sisi terima. Selain itu juga diperlukan rangkaian hand-shaking yang berfungsi agar bagian pengiriman data tidak mengirimkan data terlalu cepat yang dapat mengakibatkan bagian penerimaan data tidak sempat untuk menerima data.

\section{Komunikasi Data UART}

IC UART (Universal Asynchronous Receiver Transmitter) dibuat khusus untuk mengubah data parallel menjadi data serial dan menerima data serial yang kemudian dirubah lagi menjadi data parallel. Pada UART, kecepatan pengiriman data (Baud Rate) dan fase clock pada sisi transmitter dan sisi receiver harus sinkron, untuk itu diperlukan sinkronisasi antara transmitter dan receiver. Hal ini dilakukan oleh bit "Start" dan bit "Stop". Ketika saluran transmisi dalam keadaan idle, output UART adalah dalam keadaan logika "1". 


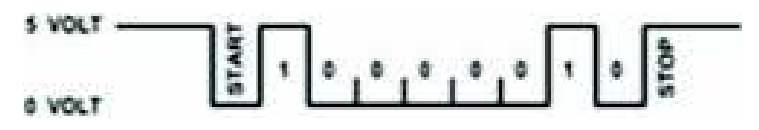

Gambar 5: Pengiriman hufur "A" tanpa bit paritas.

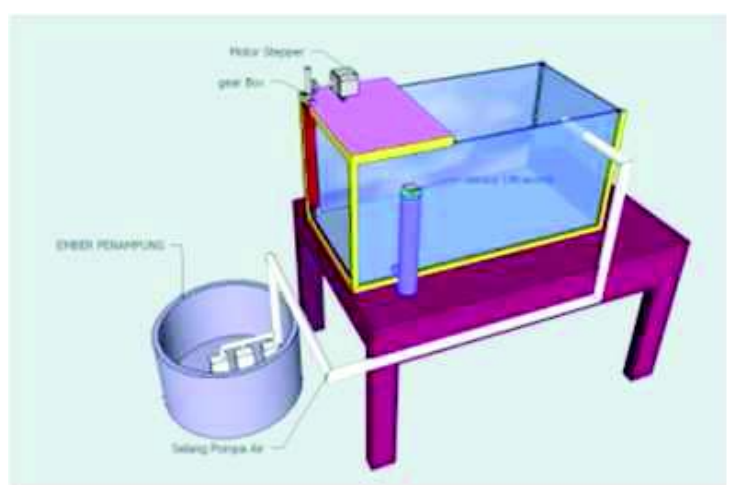

Gambar 6: Gambaran umum sistem.

Ketika transmitter ingin mengirimkan data, output UART akan diset dulu ke logika "0" untuk waktu satu bit. Sinyal ini pada receiver akan dikenali sebagai sinyal "Start" yang digunakan untuk menyinkronkan fase clocknya sehingga sinkron dengan fase clock transmitter. Selanjutnya data akan dikirimkan secara serial dari bit yang paling rendah (bit0) sampai bit tertinggi.Selanjutnya akan dikirimkan sinyal "Stop" sebagai akhir dari pengiriman data serial. Sebagai contoh misalnya akan dikirimkan data huruf "A" dalam format ASCII (atau sama dengan 41 heksa atau 01000001 ).

Kecepatan transmisi dapat dipilih bebas dalam rentang tertentu. Baud rate yang umum dipakai adalah $110,135,150$, 300, 600, 1200, 2400, dan 9600 (bit/per detik).Dalam komunikasi data serial, baud rate dari kedua alat yang berhubungan harus diatur pada kecepatan yang sama. Selanjutnya harus ditentukan panjang data (6,7 atau 8 bit), paritas (genap, ganjil, atau tanpa paritas), dan jumlah bit "Stop" (1, $1 \frac{1}{2}$, atau 2 bit). Untuk dapat menggunakan port serial harus diketahui dahulu alamat dari port serial tersebut. Biasanya tersedia dua port serial pada CPU, yaitu COM1 dan COM2.

\section{METODOLOGI}

\section{Perancangan Sistem Mini Plant}

Secara umum sistem yang dibuat seperti pada Gambar 6, sistem peraga bendungan merupakan mini plant dari sebuah bendungan sebenarnya. Sistem peraga bendungan ini berbentuk bejana kaca yang berdimensi $60 \mathrm{~cm} \times 30 \mathrm{~cm} \times 30 \mathrm{~cm}$, dengan melubangi bagian depan kaca berukuran $25 \mathrm{~cm} \times 3 \mathrm{~cm}$ sebagai pintu air. Lubang pintu air ini digunakan sebagai pengendali level ketinggian air. Air yang telah dikendalikan ket-

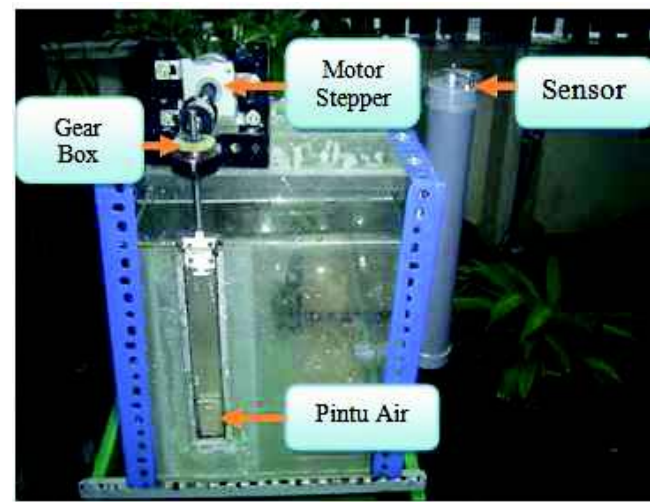

Gambar 7: Mini plant bendungan.

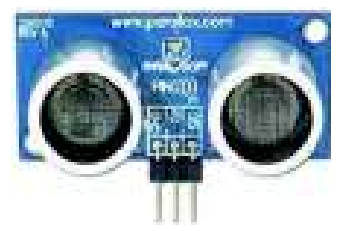

Gambar 8: Sensor ping ultrasonik.

inggiannya ini akan dideteksi melalui sensor Ping Ultrasonik. Penempatan sensor ultrasonik ini didesain secara khusus dengan memasang tabung diameter $6 \mathrm{~cm}$ pada bagian samping bejana kaca. Penempatan tabung ini digunakan untuk meminimalisir akibat guncangan dari air dalam bejana.Untuk gambar sistem lebih jelasnya dapat dilihat seperti dalam Gambar 7.

\section{Perancangan Sistem Elektronika dan Kontrol}

Sistem elektronika dan kontrol pada penelitian ini memiliki empat komponen penting yaitu :

1. Sensor

Pada dasarnya sensor Ping Ultrasonik ini terdiri dari sebuah chip pembangkit sinyal $40 \mathrm{kHz}$, terdapat 3 pin yang digunakan untuk jalur power supply $(+5 \mathrm{~V})$, ground dan signal. Sensor yang digunakan seperti ditunjukkan pada Gambar 8 .

2. Komunikasi Data

Komunikasi data yang digunakan adalah komunikasi data serial to USB yang menggunakan mikrokontroller jenis AVR ATMega8 sebagai converter serial to USB. Converter komunikasi data serial to USB menggunakan alat seperti pada Gambar 9.

3. Kontrol

Unit kontrol yang digunakan adalah mikrokontrol jenis AVR ATMega16. Mikrokontroler ATMega16 yang digunakan seperti ditunjukkan pada Gambar 10.

4. Aktuator

Rangkaian driver seperti pada Gambar 11. 


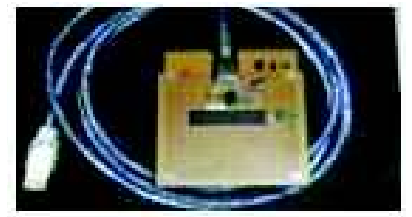

Gambar 9: Converter serial to USB dengan ATMega8.

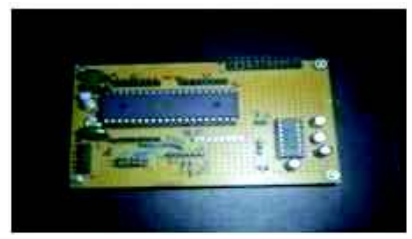

Gambar 10: Mikrokontroler ATMega16.

\section{HASIL DAN PEMBAHASAN}

\section{Data}

Data pengujian sensor ultasonik ditunjukkan dalam Tabel I dan Tabel II. Pada Tabel I ini dapat dilihat adanya perbedaan pembacaan kedalaman air antara sensor dengan pembacaan pada mistar, perbedaan ini selisih satu antara kedalaman air terbaca pada mistar (H Mistar) dengan pada sensor (Kedalaman Air Terbaca Sensor). Berbeda sekali dengan data pengujian sensor ultrasonik pada saat level ketinggian air turun yaitu pada Tabel II. Perbedaan data saat level ketinggian air naik ini terjadi bisa dikarenakan kondisi air yang diindra sensor kecenderungan masih belum stabil.

Data pada tabel ada sedikit perbedaan antara data yang terbaca oleh sensor saat level ketinggian air naik dengan data yang terbaca oleh sensor saat level ketinggian air turun. Perbedaan data ini terletak saat ketinggian air $14 \mathrm{~cm}$ sampai $17 \mathrm{~cm}$. Pada saat ketinggian air naik $14 \mathrm{~cm}$ terhadap mistar data yang terbaca oleh sensor adalah $28 \mathrm{~cm}$ sedangkan data ketinggian air turun $14 \mathrm{~cm}$ terhadap mistar data yang terbaca oleh sensor $27 \mathrm{~cm}$. Perbedaan data ini terjadi bisa dikarenakan kesalahan pembacaan pengamat terhadap mistar (error parallax) sehingga terjadi selisih data waktu ketinggian air naik maupun saat waktu ketinggian air turun, atau perbedaan data ini terjadi bisa dikarenakan terjadinya adanya pembacaan sen-

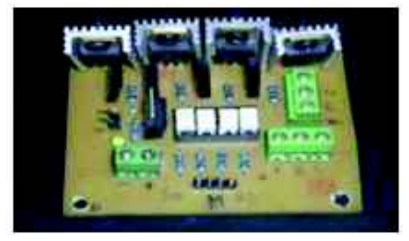

Gambar 11: Driver motor stepper.
TABEL I: Data pengujian sensor ultrasonik level air naik (Kenaikan Air)

\begin{tabular}{cccc}
\hline No & $\begin{array}{c}\mathrm{H} \\
\text { Mistar(cm) }\end{array}$ & $\begin{array}{c}\mathrm{h} \\
\text { Sensor }(\mathrm{cm})\end{array}$ & $\begin{array}{c}\text { Kedalaman Air Terbaca } \\
\text { Sensor }(\mathrm{cm})\end{array}$ \\
\hline 1 & 3 & 39 & 2 \\
2 & 4 & 38 & 3 \\
3 & 5 & 37 & 4 \\
4 & 6 & 36 & 5 \\
5 & 7 & 35 & 6 \\
6 & 8 & 34 & 7 \\
7 & 9 & 33 & 8 \\
8 & 10 & 32 & 9 \\
9 & 11 & 31 & 10 \\
10 & 12 & 30 & 11 \\
11 & 13 & 29 & 12 \\
12 & 14 & 28 & 13 \\
13 & 15 & 27 & 14 \\
14 & 16 & 26 & 15 \\
15 & 17 & 25 & 16 \\
\hline \hline
\end{tabular}

TABEL II: Data pengujian sensor ultrasonik level air turun (Penurunan Air)

\begin{tabular}{cccc}
\hline \hline No & $\begin{array}{c}\mathrm{H} \\
\text { Mistar(cm) }\end{array}$ & $\begin{array}{c}\mathrm{h} \\
\text { Sensor }(\mathrm{cm})\end{array}$ & $\begin{array}{c}\text { Kedalaman Air Terbaca } \\
\text { Sensor }(\mathrm{cm})\end{array}$ \\
\hline 1 & 27 & 14 & 27 \\
2 & 26 & 15 & 26 \\
3 & 25 & 16 & 25 \\
4 & 24 & 17 & 24 \\
5 & 23 & 18 & 23 \\
6 & 22 & 19 & 22 \\
7 & 21 & 20 & 21 \\
8 & 20 & 21 & 20 \\
9 & 19 & 22 & 19 \\
10 & 18 & 23 & 18 \\
11 & 17 & 24 & 17 \\
12 & 16 & 25 & 16 \\
13 & 15 & 26 & 15 \\
14 & 14 & 27 & 14 \\
15 & 13 & 29 & 13 \\
\hline \hline
\end{tabular}

sor yang berbeda, yaitu perbedaan antara pengukuran waktu saat air naik dan saat air turun. Pengukuran waktu yang dimaksud adalah waktu pantul sinyal dari transmitter ke receiver. Perbedaan ini diakibatkan masih terdapat gelembunggelembung yang menyebabkan pemancaran sinyal dari transmitter tidak maksimal. Untuk mencari (Kedalaman Air Terbaca Sensor) dapat dijelaskan dari Gambar 12.

Dari Gambar 12, harga (Kedalaman Air Terbaca Sensor) dapat diketahui dari tinggi dari dasar bejana kaca hingga ujung sensor dengan nilai $41 \mathrm{~cm}$ dikurangi dengan data yang terbaca oleh sensor (h sensor). Karena data yang terbaca dari sensor adalah data jarak dari permukaan air sampai ujung sensor. Sehingga dari data kedalaman air yang terbaca oleh mistar $(\mathrm{H}$ mistar) dengan data kedalaman air yang terbaca oleh sensor (Kedalaman Air Terbaca Sensor) dapat dibuat korelasi menjadi grafik. Dari Tabel I dan Tabel II dibuat grafik untuk melihat keseksamaan antara (Kedalaman Air Terbaca Sensor) dengan kedalaman air menurut mistar yaitu (H mistar). 


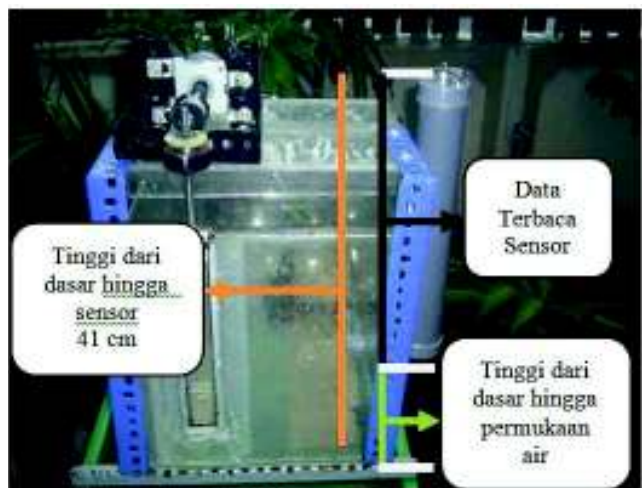

Gambar 12: Mencari h level sensor dari konstruksi mini plant.

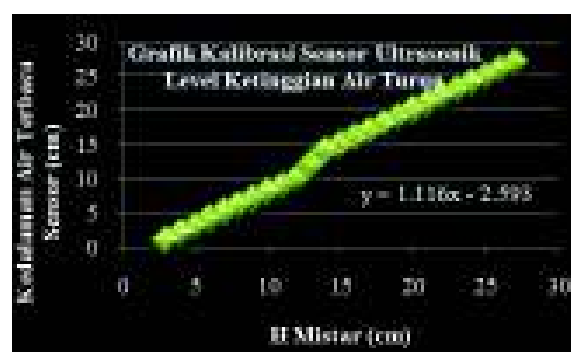

Gambar 13: Grafik hubungan antara (H mistar) dengan (Ketinggian Air Terbaca Sensor) saat level air turun.

\section{Mekanisme Pengendalian.}

Untuk mekanisme pengendalian otomatis dapat dilihat pada Gambar 15, sedangkan untuk mekanisme pengendalian manual dapat dilihat pada Gambar 16.

\section{SIMPULAN}

Simpulan yang dapat diambil dari penelitian ini adalah (a). sensor ping ultrasonik dapat digunakan sebagai sensor level ketinggian air, (b). dari grafik didapatkan bahwa sensor ping ultrasonic bersifat linier, (c). sistem yang dibuat telah dapat

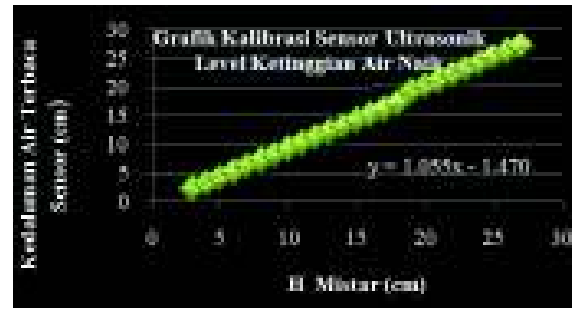

Gambar 14: Grafik hubungan antara (H mistar) dengan (Kedalaman Air Terbaca Sensor) saat level air naik.

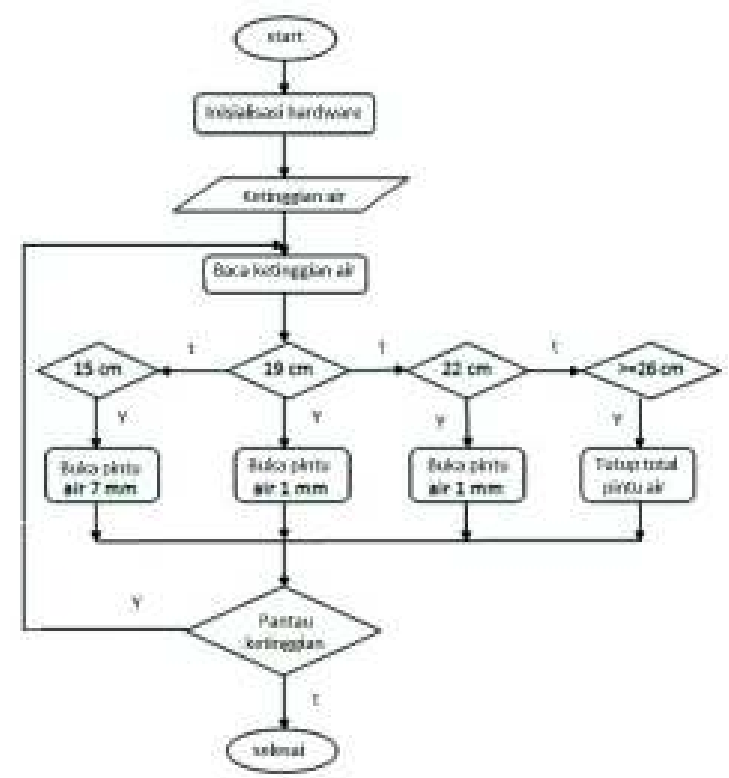

Gambar 15: Mekanisme pengendalian otomatis.
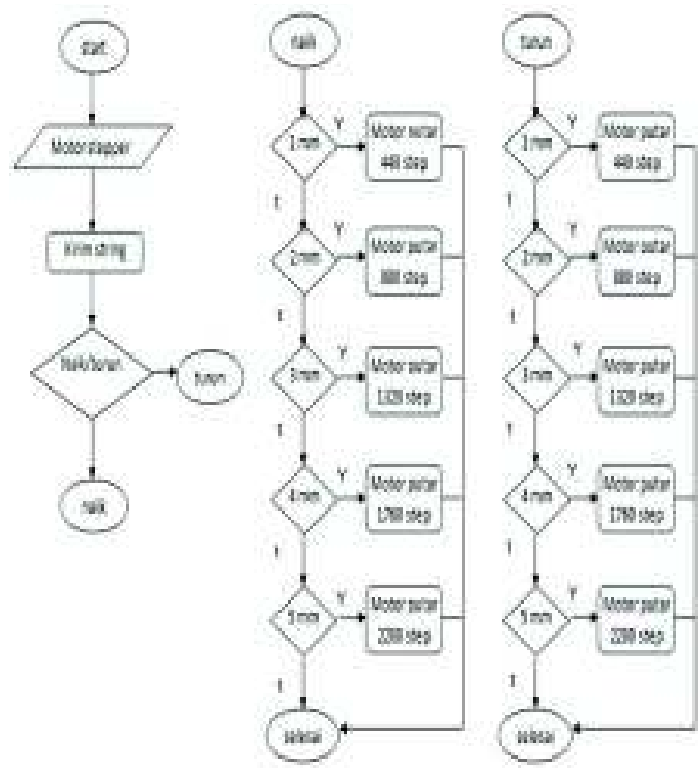

Gambar 16: Mekanisme pengendalian manual.

mengendalikan membuka dan menutup pintu air pada mini plant bendungan secara otomatis maupun secara manual. 
[1] Kartasapoetra, A.G., Teknologi Pengairan Pertanian Irigasi (Bumi Aksara, Jakarta, 1991) .

[2] Budiharto, Widodo, 10 proyek robot Spektakuler (Elex Media Komputindo dan Gramedia, Jakarta, 2008).

[3] Andrianto,Heri, Pemrograman Mikrokontroller (AVR ATMEGA 16, Bandung, INFORMATIKA, 2008).

[4] --, Komunikasi Serial (http://digilib.ubaya.ac.id/skripsi/ teknik/TE-32-6871020/TE-32-Bab\%20II.pdf)

[5] --, Komunikasi Serial to UART (http://blog.ub.ac.id/ vbrue/ 2010/ 03/21/ interfacing-port-serial-rs-232-dengan-uart/)

[6] Munasir, "Fluida Dinamis (Departemen Pendidikan Nasional, Jakarta, 2004) (http://azkamiru.files.wordpress.com/2010/01/fis 14-fluida-dinamis1.pdf)

[7] Munson, Bruce R. Young, Donald F. Okiishi, Theodore H.,
Mekanika Fluida jilid 1 (edisi keempat, Penerbit Erlangga, Jakarta, 2003).

[8] Ogata, Katsuhiko, Teknik Kontrol Automatik jilid 1 (edisi kedua, Penerbit Erlangga, Jakarta, 1997).

[9] —-, Sensor Ultrasonik, (http://atmelmikrokontroler.wordpress.com/ 2009/06/24/prinsip-kerja-rangkaian-sensor-ultrasonik/)

[10] Setiawan, Dedy, Sistem Monitoring Ketinggian Air pada Bendungan secara Jarak Jauh dengan Memanfaatkan Gelombang Radio, Tugas Akhir Program STudi D3 Teknik Elektro-FTI, Institut Teknologi Sepuluh Nopember, Surabaya, 2009.

[11] Wahana Komputer, Tim penelitian dan Pengembangan, Teknik Antar Muka Mikrokontroller dengan Komputer Berbasis Delphi (Salemba Infotek, Jakarta, 2006). 